\title{
IDENTIFICATION OF A MUTATION IN THE SPIKE PROTEIN CLEAVAGE SITE IN BRAZILIAN STRAINS OF WILD-TYPE BOVINE CORONAVIRUS
}

\author{
Elisabete Takiuchi ${ }^{1}$; Marco Antônio Bacellar Barreiros ${ }^{2}$; Alice Fernandes Alfieri ${ }^{1}$; Amauri Alcindo Alfieri ${ }^{1 *}$ \\ ${ }^{1}$ Laboratório de Virologia Animal, Departmento de Medicina Veterinária Preventiva, Universidade Estadual de Londrina, \\ Londrina, PR, Brasil; ${ }^{2}$ Laboratório de Microbiologia, Universidade do Vale do Itajaí, Itajaí, SC, Brasil
}

Submitted: May 30, 2007; Returned to authors for corrections: September 17, 2007; Approved: September $28,2007$.

\begin{abstract}
The spike (S) protein of coronaviruses, a type I membrane glycoprotein, is primarily responsible for entry into susceptible cells by binding with specific receptors on cells and mediating subsequent virus-cell fusion. The bovine coronavirus (BCoV) S protein is cleaved into two subunits, the $\mathrm{N}$-terminal S1 and the C-terminal S2. The proteolytic cleavage site of S protein is highly conserved among BCoV strains and is located between amino acids 763 and 768 (KRRSRR). This study describes a single mutation in the $\mathrm{S}$ protein cleavage site of three Brazilian strains of $\mathrm{BCoV}$ detected in diarrheic fecal samples from calves naturally infected. The sequenced PCR products revealed that amino acid sequence of the cleavage site of our strains was KRRSSR, indicating a mutation at amino acid position $767(\mathrm{R} \rightarrow \mathrm{S})$. This amino acid substitution occurred due to a single nucleotide substitution in the sequence of DNA corresponding to the proteolytic cleavage site, CGT to AGT. This is the first description of this nucleotide mutation ( $\mathrm{C}$ to $\mathrm{A}$ ), which resulted in the substitution of arginine to serine in the $\mathrm{S}$ cleavage site. In this study we speculated the probable effects of this mutation in the proteolytic cleavage site using the murine hepatitis coronavirus (MHV) as a comparative model.
\end{abstract}

Key words: $\mathrm{BCoV}$, sequencing, spike protein, cleavage site, mutation

Bovine coronavirus (BCoV), a member of the family Coronaviridae, order Nidovirales, belongs to group 2 of the coronaviruses which include murine hepatitis coronaviruses (MHV), porcine hemagglutinating encephalomyelitis virus $(\mathrm{HEV})$, equine coronavirus $(\mathrm{ECoV})$, rat coronavirus $(\mathrm{RtCoV})$ and human respiratory coronavirus (HCoV-OC43) (9). $\mathrm{BCoV}$ is an enveloped virus with single-stranded, positive-sense RNA genome of approximately $32 \mathrm{~kb}$ length that encodes five major structural proteins: the nucleocapsid $(\mathrm{N})$, the transmembrane $(\mathrm{M})$, the hemaglutinin esterase (HE), the spike (S), and the small protein (E) (13). The $\mathrm{S}$ glycoprotein of $\mathrm{BCoV}$ is a large membrane glycoprotein of approximately $150 \mathrm{kDa}$ that forms the peplomers (club-shaped structures) on the virion surface. The $\mathrm{S}$ protein is primarily responsible for the entry of coronavirus into susceptible cells by binding to specific receptors on cells and mediating virus-cell fusion and subsequent cell-cell fusion during infection (5).
In several coronaviruses, such as infectious bronchitis virus (IBV), MHV and $\mathrm{BCoV}$, as a late event in maturation, the protein is cleaved into two subunits: S1 (aminoterminal region) and S2 (carboxyterminal region) (17). Proteolytic cleavage of the S protein of these coronaviruses occurs adjacent to a sequence of basic amino acids on the carboxyterminal region of S1. In the $\mathrm{S}$ protein of $\mathrm{BCoV}$, a predicted basic amino acid sequence (KRRSRR) is involved in the cleavage by the host cell-derived proteolytic enzyme. This sequence, highly conserved among BCoV strains, encompasses amino acids 763 to 768 ; the cleavage occurs between amino acids 768 and 769 (19). The cleavage of the $S$ protein has been reported as a process related to the viral infectivity and cell fusion from other group 2 coronaviruses. Studies related to MHV, the best-studied member of the Coronavirus family, demonstrated that cleavage of $\mathrm{S}$ is not essential for infectivity but is associated with enhanced cell fusion (syncytia) in infected cell monolayers $(7,8,20)$.

*Corresponding Author. Mailing address: Departamento de Medicina Veterinária Preventiva, Centro de Ciências Agrárias, Universidade Estadual de Londrina, Londrina, PR, Brasil. Caixa Postal 6001, CEP 86051-990. Tel.: +55 433371 4485; Fax: +55 43 3371-4714. E-mail: alfieri@uel.br 
This study describes a single mutation in the $\mathrm{S}$ protein cleavage site of wild type Brazilian strains of $\mathrm{BCoV}$ detected in calves naturally infected and speculates the possible biological effects of this mutation at the proteolytic cleavage site using the MHV as a comparative model.

Three BCoV positive fecal samples (BR-UEL1, BR-UEL2 and BR-UEL3) were obtained from calves up to 30 days old with clinical signs of diarrhea in a Brazilian dairy herd from Minas

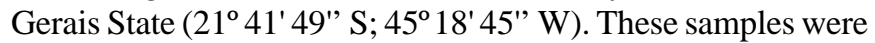
previously identified as $\mathrm{BCoV}$ positive by RT-PCR assay for $\mathrm{N}$ gene detection (21) and negative for bovine group A rotavirus and Cryptosporidium sp by polyacrylamide gel electrophoresis technique and modified Ziehl-Nielsen method. Fecal samples were diluted 2-fold in $0.01 \mathrm{M}$ phosphate-buffered saline (PBS) pH $7.2\left(137 \mathrm{mM} \mathrm{NaCl} ; 3 \mathrm{mM} \mathrm{KCl} ; 8 \mathrm{mM} \mathrm{Na} 2 \mathrm{HPO}_{4} ; 15 \mathrm{mM}\right.$ $\mathrm{KH}_{2} \mathrm{HPO}_{4}$ ), centrifuged at $3000 \mathrm{x}$ for $15 \mathrm{~min}$ at $4^{\circ} \mathrm{C}$ to remove the cell debris. The supernatants were used for RNA extraction. Aliquots of $400 \mu \mathrm{l}$ from fecal suspensions were treated with SDS at a final concentration of $1 \%(\mathrm{w} / \mathrm{v})$, homogenized by vortexing and kept at $56^{\circ} \mathrm{C}$ for $30 \mathrm{~min}$. A combination of phenol/chloroform/ isoamyl alcohol and silica/guanidinium isothiocyanate methods was performed according to Barreiros et al. (1) with slight modifications. Briefly, $400 \mu \mathrm{l}$ of phenol/chloroform/isoamyl alcohol (25:24:1) were added, vortexed and heated at $56^{\circ} \mathrm{C}$ for 15 $\min (16)$. The mixture was centrifuged at $10,000 \mathrm{x} g$ for $10 \mathrm{~min}$ and the supernatant was transferred into a new tube and processed by the silica/guanidinium isothiocyanate method (2). The RNA was eluted from the silica pellet with $50 \mu$ l of diethylpyrocarbonate (DEPC) treated sterile water by $15 \mathrm{~min}$ incubation at $56^{\circ} \mathrm{C}$ and centrifuged at $10,000 \times g$ for $10 \mathrm{~min}$. The supernatant fraction was kept at $-20^{\circ} \mathrm{C}$ until further use.

Specific oligonucleotide primers that flank the sequence corresponding to $\mathrm{S}$ protein cleavage site were designed using the Gene Runner program version 3.05 (Hastings Software Inc., Hastings, NY) (http://www.generunner.com). The primers sequences (positions calculated from the start codon of the $S$ gene) were: SPK7_F: 5' -TAACTCTTCCGAACCAGCA-3' (nt 2085-2103) and SPK7_R: 5'-AATCGCTTCCTAAACAACC-3' (nt 2701-2719), which amplify a predicted fragment of $636 \mathrm{bp}$.

The reverse transcription (RT) reaction was performed with a mixture of $8 \mu$ of extracted RNA and $2 \mu \mathrm{l}$ of the random primer pdN6 (GE Healthcare, Little Chalfont, UK) and incubated at $97^{\circ} \mathrm{C}$ for $4 \mathrm{~min}$. Subsequently, it was placed on ice for $5 \mathrm{~min}$ and $10 \mu \mathrm{l}$ of RT mix containing $1 \mathrm{x}$ RT buffer $(50 \mathrm{mM}$ Tris-HCl, $\mathrm{pH} 8.3$, $\left.3 \mathrm{mM} \mathrm{MgCl}_{2}, 75 \mathrm{mM} \mathrm{KCl}\right), 0.1 \mathrm{mM}$ of each dNTP (Invitrogen $^{\mathrm{TM}}$ Life Technologies, USA), 10 mM DTT, 100 units of M-MLV Reverse Transcriptase (Invitrogen ${ }^{\mathrm{TM}}$ Life Technologies, USA) and ultrapure sterile water to a final volume of $20 \mu \mathrm{l}$ were added and incubated at $37^{\circ} \mathrm{C}$ for $60 \mathrm{~min}$ and followed by inactivation at $95^{\circ} \mathrm{C}$ for $5 \mathrm{~min}$.

For amplification, $8 \mu \mathrm{l}$ of the RT reaction were added to $42 \mu \mathrm{l}$ of the PCR mix containing $1.5 \times$ PCR buffer ( $30 \mathrm{mM}$ Tris- $\mathrm{HCl} \mathrm{pH}$
8.4 and $75 \mathrm{mM} \mathrm{KCl}), 2 \mathrm{mM} \mathrm{MgCl} 2,0.2 \mathrm{mM}$ of each dNTP, $1 \mu \mathrm{l}(20$ pmol) of each primer, 2.5 units Platinum Taq DNA polymerase (Invitrogen ${ }^{\mathrm{TM}}$ Life Technologies, USA) and ultrapure sterile water to a final volume of $50 \mu$. The reaction was performed in a thermocycler (PTC-200, MJ Research Co. Water Town, MA, USA) with the following time and temperature conditions: one step of $4 \mathrm{~min} / 94^{\circ} \mathrm{C}$; followed by 40 cycles of $1 \mathrm{~min} / 94^{\circ} \mathrm{C}, 1 \mathrm{~min} /$ $52^{\circ} \mathrm{C}, 1 \mathrm{~min} / 72^{\circ} \mathrm{C}$ and a final step of $7 \mathrm{~min} / 72^{\circ} \mathrm{C}$.

The products were analyzed by electrophoresis in a $2 \%$ agarose gel in TBE buffer $\mathrm{pH} 8.4$ ( $89 \mathrm{mM}$ Tris; $89 \mathrm{mM}$ boric acid; $2 \mathrm{mM}$ EDTA $)$, stained with ethidium bromide $(0.5 \mu \mathrm{g} / \mathrm{ml})$ and visualized under UV light.

The PCR amplicons were purified using GFX PCR DNA and Gel Band Purification (GE Healthcare, Little Chalfont, UK) and sequenced in MegaBACE 1000/Automated 96 Capillary DNA Sequencer (GE Healthcare), according to the manufacturer's instructions. Sequencing was performed in both directions using the forward (F) and reverse (R) primers. Sequences quality analysis was performed using Phred/Phrap/Consed Analysis Program (http://www.phrap.org) and sequence similarity search was performed using BLAST software (http:// www.ncbi.nlm.nih.gov/BLAST/). The nucleotide sequences of the wild-type Brazilian BCoV strains were aligned and compared with the $\mathrm{BCoV}$ reference strains using the CLUSTAL/W program.

The sequences reported in this study have been deposited in the GenBank database under accession numbers: DQ479421 (BR-UEL1), DQ479422 (BR-UEL2) and DQ479423 (BR-UEL3). The predicted secondary structure, hydrophilicity profile and protease map were determined using Protean of DNAStar software (DNAStar, Inc., Madison, WI, USA).

The amino acid sequence of the cleavage site of the three wild-type Brazilian BCoV strains was KRRSSR, indicating an amino acid mutation at position $767(\mathrm{R} \rightarrow \mathrm{S})$. Divergence in amino acid sequence of the $\mathrm{S}$ protein cleavage site among coronaviruses strains are indicated in Fig. 1.

The only mutation described in the proteolytic cleavage site of bovine coronaviruses was reported in 1991 with the wild type French BCoV strain F-15, which also showed an amino acid substitution at position $767(\mathrm{R} \rightarrow \mathrm{V})$ (Fig. 1). However, the authors did not discuss the effects related to the amino acid change (24).

Sequence analysis suggested that the BCoV BR-UEL sequences were trustworthy and not the result of RT-PCR or sequencing errors, since the same mutation was successfully amplified and sequenced in all samples and also in different fecal aliquots from each animal. Furthermore, the mutations associated with viral adaptation in cell culture were excluded, since the samples did not undergo cell culture passage prior to PCR amplification and sequencing.

Although there are no study related to mutational analysis in the proteolytic cleavage site of $\mathrm{BCoV}$ strains, this phenomenon has been previously described for MHV strain. Computational analysis demonstrated that the HCoV-OC43, 


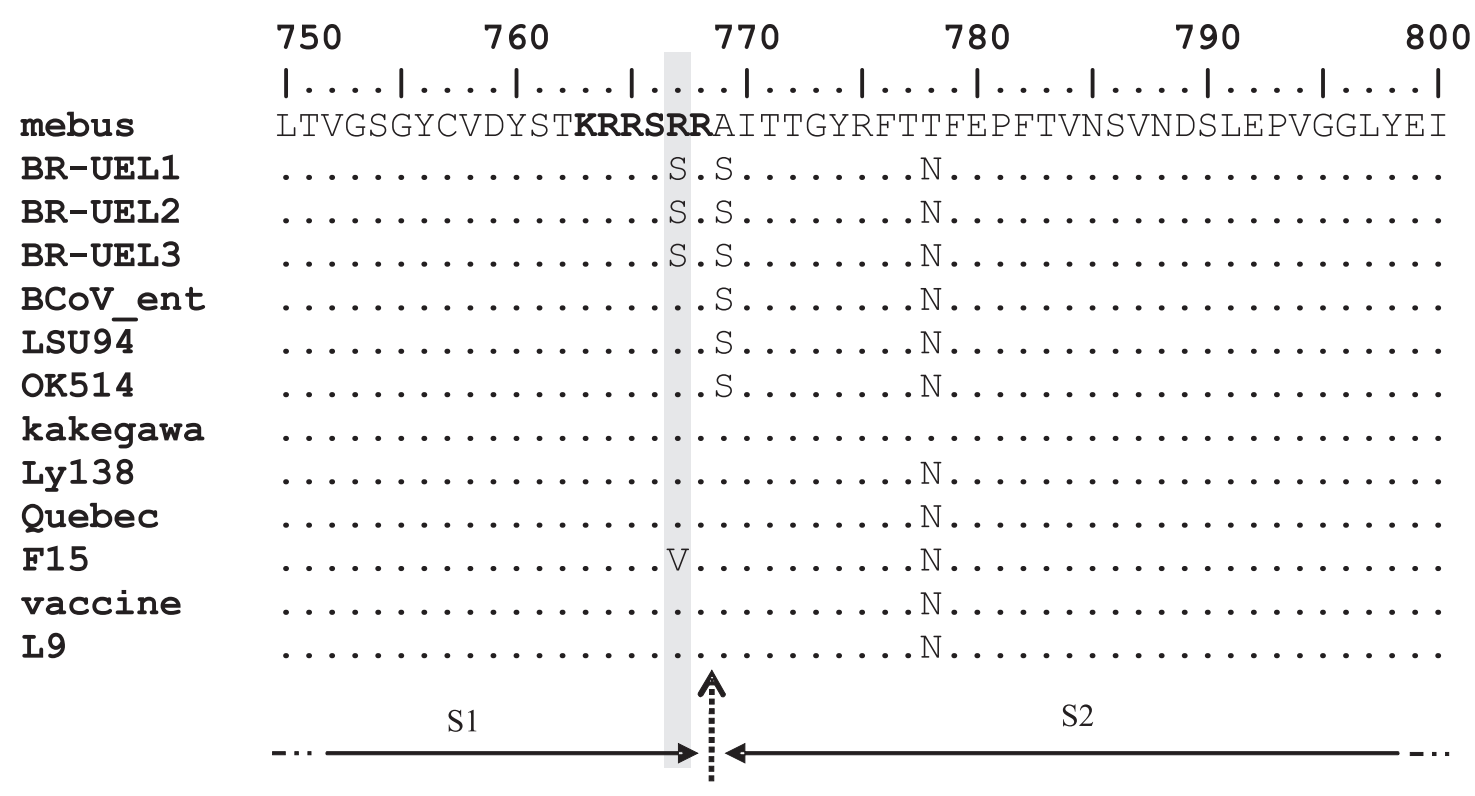

Cleavage site

Figure 1. Predicted amino acid sequences for the spike gene in the cleavage site proximities. Residues in bold represents proteolytic cleavage signal sequence of the Mebus strain. The arrow between amino acids 768 and 769 indicates the cleavage site between S1 and S2. Shaded residue indicates the mutation in the cleavage signal. BCoV BR-UEL strains (GenBank accession numbers DQ479421, DQ479422, DQ479423), Mebus (U00735), BCoV ENT (AF391541), LSU94 (AF058943), OK514 (AF058944), Kakegawa (DQ479424), LY138 (AF058942), Quebec (AF220295), F15 (D00731), Vaccine (M64668), L9 (M6466).

MHV-A59 and BCoV presented high degree of identity among group 2 coronaviruses (18). Based on these evidences, the MHV was used as an appropriate model to hypothesize the effects of the new mutation observed in the $\mathrm{S}$ protein cleavage signal of wild-type BCoV strains during this study.

Cleavage of $\mathrm{S}$ protein is related to efficient cell-cell fusion (syncytia) by MHV in infected cell monolayers but is not necessary for virus-cell fusion (infectivity). The MHV spike proteins, that have mutations that eliminate cleavage into S1 and S2 subunits, carry out cell-to-cell fusion very inefficiently; however, they are able to mediate entry into susceptible cells with similar efficiency as wild-type virus $(3,8,14)$. Although the cleavage of the $\mathrm{S}$ protein is not a prerequisite for fusion, it does enhance the induction of syncytia (3). Hingley et al. (12) and Hann et al. (10) reported that the cleavage of the S protein of MHV-A59 mutant was greatly reduced in comparison with the wild-type virus. The sequence at the predicted cleavage site of MHV-A59 wild-type is RRAHR while that of MHV-A59 mutant is RRADR. The MHV-A59 mutant showed a substitution of a weakly basic histidine $(\mathrm{H})$ by negatively charged aspartic acid (D) in the cleavage signal (8). These authors suggest that the introduction of a negatively charged amino acid into this highly basic region destroys the signal or otherwise prevents its recognition and thereby inhibits cleavage of the spike.
Similar to MHV, BCoV S gene also has a proteolytic cleavage site formed by a group of basic amino acids upstream from the S2 amino terminal region. Except for BCoV F15, this sequence is highly conserved in all known $\mathrm{BCoV}$ strains (KRRSRR). In the BCoV BR-UEL samples was identified an amino acid substitution $(\mathrm{R} \rightarrow \mathrm{S})$ at amino acid position 767 (KRRSSR) (Fig. 1). This amino acid change occurred due to a single nucleotide mutation at the proteolytic cleavage site, CGT to AGT. This mutation ( $\mathrm{C}$ to $\mathrm{A})$, that resulted in the change of the arginine codon to serine, had never been described. The cleavage into the two subunits occurs between amino acid 768 and 769 and is thought to be mediated by cellular trypsin-like proteases (19). The protease map indicated that three BR-UEL strains lack one predicted cleavage site by trypsin when compared with other known BCoV. In MHV studies there are strong evidence that furin enzyme is the cell protease responsible for cleavage of the S protein in cultured cells (10). In addition, although it did not alter the predicted secondary structure or hydrophilicity of the protein, the substitution of arginine to serine is a nonconservative substitution. Nonconservative amino acid changes within a single protein may result in alterations of the physical energy of the protein-protein interaction and may destabilize the protein native conformation (6). Navas-Martin et al. (15) suggest that the proper spatial 
arrangement of the S1 and S2 subunits is crucial for the biological functions of the $\mathrm{S}$ protein.

Yoo and Deregt (23) generated BCoV mutants and confirmed that a single point mutation at domain II of S1 protein was responsible for the escape of $\mathrm{BCoV}$ from immunological response. Similarly, He et al. (11) described that a single amino acid substitution in the receptor-binding domain of SARS coronavirus $\mathrm{S}$ protein disrupted the antigenic structure and binding activity. In addition, a single amino acid change has already been demonstrated to influence MHV ability to spread within the central nervous system (22).

Recently, Navas-Martin et al. (15) have demonstrated that a single cleavage signal substitution in MHV mutants may play a major role in the virulence. These authors have associated this mutation with higher viral load and highly virulent phenotypes. Interestingly, the BR-UEL strains were obtained during an outbreak of neonatal diarrhea that culminated with the death of calves in a Brazilian dairy cattle herd. Because BCoV infections resulting in high mortality is uncommon, the results described by Navas-Martin et al. (15) for MHV strain should be also investigated for $\mathrm{BCoV}$ proteolytic cleavage site mutants. Divergence within the $\mathrm{S} 1$ gene of others BCoV Brazilian strains had already been described by Brandão et al. (4). These authors reported the first description of a gap of 18 nucleotides (deletion of 6 amino acids) within the hypervariable region of the S1 subunit from their isolates and that was also found in human coronavirus strain OC43.

We are uncertain if this single mutation prevented the normal proteolytic cleavage of the $\mathrm{S}$ protein or increased viral load, as occurred in MHV mutants. Therefore, additional experiments must be done to determine the effects of the amino acid change $(\mathrm{R} \rightarrow \mathrm{S})$ within the proteolytic cleavage site on the structural and functional features of the BCoV S protein. Development of a system which introduces infectious cDNA clones with specific mutations into the $\mathrm{BCoV}$ genome will provide an important tool to determine the role of these $\mathrm{BCoV}$ mutants in the pathogenesis of the neonatal calf diarrhea.

\section{ACKNOWLEDGMENTS}

We thank the Brazilian Institutes CNPq, CAPES, FINEP and Fundação Araucária (FAP/PR) for financial support. A.A. Alfieri and A.F. Alfieri are recipients of $\mathrm{CNPq}$ fellowship.

\section{RESUMO}

\section{Identificação de uma mutação no sítio de clivagem da proteína da espícula em amostras brasileiras de coronavírus bovino}

A proteína da espícula (S), uma glicoproteína de membrana do tipo I, é primariamente responsável pela entrada do vírus em células susceptíveis por meio da interação inicial com receptores celulares específicos e subseqüente mediação da fusão víruscélula. A proteína $\mathrm{S}$ do coronavírus bovino $(\mathrm{BCoV})$ é clivada em duas subunidades: a $\mathrm{S} 1$, na região $\mathrm{N}$-terminal e a $\mathrm{S} 2$, na região C-terminal. O sítio de clivagem proteolítica da proteína S é altamente conservado entre as estirpes de $\mathrm{BCoV}$ e está situado entre os aminoácidos 763-768 (KRRSRR). Este estudo descreve uma mutação no sítio de clivagem da proteína $S$ de três estirpes do $\mathrm{BCoV}$ detectadas em amostras fecais diarréicas de bezerros naturalmente infectados no Brasil. O seqüenciamento dos produtos de PCR identificou a sequiência de aminoácidos KRRSSR no sítio de clivagem de nossas amostras, indicando uma mutação na posição $767(\mathrm{R} \rightarrow \mathrm{S})$. Esta mutação ocorreu devido a uma única substituição de nucleotídeo no sítio de clivagem proteolítica, alterando o códon CGT para AGT. Esta é a primeira descrição desta mutação de nucleotídeo (C para $\mathrm{A})$, que resultou na substituição do aminoácido arginina por serina no sítio de clivagem da proteína S. Neste estudo também são sugeridos os prováveis efeitos desta mutação no sitio de clivagem proteolítica utilizando o coronavírus da hepatite dos camundongos (MHV) como um modelo comparativo.

Palavras-chave: $\mathrm{BCoV}$, seqüenciamento, proteína da espícula, sitio de clivagem, mutação

\section{REFERENCES}

1. Barreiros, M.A.; Alfieri, A.F.; Médici, K.C.; Leite, J.P.; Alfieri, A.A. (2004). G and $P$ genotypes of group A rotavirus from diarrhoeic calves born to cows vaccinated against the $\operatorname{NCDV}(\mathrm{P}[1], \mathrm{G} 6)$ rotavirus strain. J. Vet. Med. B, 51, 104-109.

2. Boom, R.; Sol, C.J.A.; Salimans, M.M.M.; Jansen, C.L.; Wertheimvan Dillen, P.M.E.; Van Der Noordaa, J. (1990). Rapid and simple method for purification of nucleic acids. J. Clin. Microbiol., 28, 495-503.

3. Bos, E.C.W.; Heijnen, L.; Luytjes, W.; Spaan, W.J.M. (1995). Mutational analysis of the murine coronavirus spike protein: effect on cell-to-cell fusion. Virology, 214, 453-463.

4. Brandão, P.E.; Gregori, F.; Richtzenhain, L.J.; Rosales, C.A.R.; Villarreal, L.Y.B.; Jerez, J.A. (2006). Molecular analysis of Brazilian strains of bovine coronavirus $(\mathrm{BCoV})$ reveals a deletion within the hypervariable region of the S1 subunit of the spike glycoprotein also found in human coronavirus OC43. Arch. Virol., 151, 17351748.

5. Cavanagh, D. (1995). The coronavirus surface glycoprotein. In: Siddell, S.G. (ed.), The Coronaviridae, Plenum Press, New York, USA, p. 73-113.

6. Davis, N.L.; Fuller, F.J.; Dougherty, W.G.; Olmsted, R.A.; Johnston, R.E. (1986). A single nucleotide change in the E2 glycoprotein gene of Sindbis virus affects penetration rate in cell culture and virulence in neonatal mice. Proc. Natl. Acad. Sci. USA, 83, 6771-6775.

7. Frana, M.F.; Behnke, J.N.; Sturman, S.; Holmes, K.V. (1985). Proteolytic cleavage of the E2 glycoprotein of murine coronavirus: host-dependent differences in proteolytic cleavage and cell fusion. J. Virol., 56, 912-920.

8. Gombold, J.L.; Hingley, S.T.; Weiss, S.R. (1993). Fusion-defective mutants of mouse hepatitis virus A59 contains a mutation in the spike protein cleavage signal. J. Virol., 67, 4504-4512. 
9. Gonzáles, J.M.; Gomez-Puertas, P.; Cavanagh, D.; Gorbalenya, A.E.; Enjuanes, L. (2003). A comparative sequence analysis to revise the current taxonomy of the family Coronaviridae. Arch. Virol., 148, 2207-2235.

10. Hann, C.A.M.; Stadler, K.; Godeke, G.J.; Bosch, B.J.; Rottier, P.J.M. (2004). Cleavage inhibition of the murine coronavirus spike protein by a furin-like enzyme affects cell-cell but not virus-cell fusion. $J$. Virol., 78, 6048-6054.

11. He, Y.; Li, J.; Jiang, S. (2006). A single amino acid substitution (R441A) in the receptor-binding domain of SARS coronavirus spike protein disrupts the antigenic structure and binding activity. Biochem. Biophys. Res. Commun., 344, 106-113.

12. Hingley, S.T.; Bombold, J.L.; Lavi, E.; Weiss, S.R. (1994). MHVA59 fusion mutants are attenuated and display altered hepatotropism. Virology, 200, 1-10.

13. Lai, M.M.C.; Cavanagh, D. (1997). The molecular biology of coronaviruses. Adv. Virus. Res., 48, 1-100.

14. Leparc-Goffart, I.; Hingley, S.T.; Chua, M.M.; Phillips, J.; Lavi, E.; Weiss, S.R. (1998). Target recombination within the spike gene of murine coronavirus mouse hepatitis virus-A59: Q159 is a determinant of hepatotropism. J. Virol., 72, 9628-9636.

15. Navas-Martin, S.; Hingley, S.T.; Weiss, S.R. (2005). Murine coronavirus evolution in vivo: functional compensation of a detrimental amino acid substitution in the receptor binding domain of the spike glycoprotein. J. Virol., 79, 7629-7640.

16. Sambrook, J.; Fritsch, E.F.; Maniatis, T. (1989). Molecular cloning: a laboratory manual, 2nd Ed. Cold Spring Harbor Laboratory Press, Cold Spring Harbor, New York.
17. Spann, W.; Cavanagh, D.; Horzineck, M.C. (1988). Coronaviruses: structure and genome expression. J. Gen. Virol., 69, 2939-2952.

18. St-Jean, J.R.; Jacomy, H.; Desforges, M.; Vabret, A.; Freymuth, F.; Talbot, P.J. (2004). Human respiratory coronavirus OC43: genetic stability and neuroinvasion. J. Virol., 78, 8824-8834.

19. Storz, J.; Rott, R.; Kaluza, G. (1981). Enhancement of plaque formation and cell fusion of an enteropathogenic coronavirus by trypsin treatment. Infect. Immun., 31, 1214-1222.

20. Sturman, L.S.; Ricard, C.S.; Holmes, K.V. (1985). Proteolytic cleavage of the E2 glycoprotein of murine coronavirus: activation of cell-fusing activity of virions by trypsin and separation of two different $90 \mathrm{~K}$ cleavage fragments. J. Virol., 56, 904-911.

21. Takiuchi, E.; Stipp, D.T.; Alfieri, A.F.; Alfieri, A.A. (2006). Improved detection of bovine coronavirus $\mathrm{N}$ gene in faeces of calves infected naturally by a semi-nested PCR assay and an internal control. $J$. Virol. Methods, 131, 148-154.

22. Tsai, J.C.; Groot, L.; Pinon, J.D.; Iacono, K.T.; Phillips, J.J.; Seo, S.H.; Lavi, E.; Weiss, S.R. (2003). Amino acid substitutions within the heptad repeat domain 1 of murine coronavirus spike protein restrict viral antigen spread in the central nervous system. Virology, 312, 369-380

23. Yoo, D.; Deregt, D. (2001). A single amino acid change within antigenic domain II of the spike protein of bovine coronavirus confers resistence to virus neutralization. Clin. Diagn. Lab. Immunol., 8, 297-302.

24. Zhang, X.; Kousoulas, K.G.; Storz, J. (1991). Comparison of the nucleotide and deduced amino acid sequences of the $\mathrm{S}$ genes specified by virulent and avirulent strains of bovine coronaviruses. Virology, $183,397-404$ 